\title{
EHMTI-0014. A case of ice-pick headache
}

\author{
D Tertan ${ }^{1 *}$, OB Tertan ${ }^{2}$ \\ From 4th European Headache and Migraine Trust International Congress: EHMTIC 2014 \\ Copenhagen, Denmark. 18-21 September 2014
}

\section{Introduction}

Ice-pick pain or ophtalmodynia periodica consists of unilateral, ultrashort and localized stabs of pain in the distribution of the first branch of the trigeminal nerve and occurs in the absence of organic disease.

\section{Aim}

To draw attention to the possibility of coexistence of a chronic migraine with a stabbing pain in a pregnant patient.

\section{Methods}

This case involves a female, aged 39, pregnant -12 weeks, experiencing stabbing light to 15-20 times per day on average. Before pregnancy, her pains were completely relieved with Indomethacin $25 \mathrm{mg}$ three times daily for seven days and $6 \mathrm{mg}$ of melatonin per day at bedtime: while continuing to take melatonin, she remained painfree at a two-month-follow-up. Because these drugs were contraindicated in her status, we used Capsaicin nasal spray which improved the reccurent ice-pick pains-4-5 attacks per day, but with extreme headache-related disability. We suggested a preventive treatment with Boswellia serrata 350-three times a day which stopped completely the reccurent ice-pick pains for the entire period of pregnancy.

\section{Results}

In this particular case, Melatonin and Indomethacin, being contraindicated, a herbal treatment was appropriate and useful. Boswellic acid inhibits prostaglandin synthesis by inhibiting the lipoxygenase pathway.

\section{Conclusion}

Physicians need to be knowledgeable about this syndrome because each has its own treatment and the patient can be

${ }^{1}$ Neurology, Clinical Hospital Pelican, Oradea, Romania

Full list of author information is available at the end of the article burdened with excruciating headache-related disability. Boswellia might be an effective option for it.

No conflict of interest.

Authors' details

${ }^{1}$ Neurology, Clinical Hospital Pelican, Oradea, Romania. ${ }^{2}$ University of Medicine and Pharmacy, Cluj Napoca, Romania.

Published: 18 September 2014

doi:10.1186/1129-2377-15-S1-D64

Cite this article as: Tertan and Tertan: EHMTI-0014. A case of ice-pick

headache. The Journal of Headache and Pain 2014 15(Suppl 1):D64.
Submit your manuscript to a SpringerOpen ${ }^{\circ}$ journal and benefit from:

- Convenient online submission

- Rigorous peer review

- Immediate publication on acceptance

- Open access: articles freely available online

- High visibility within the field

- Retaining the copyright to your article

Submit your next manuscript at $\boldsymbol{s p r i n g e r o p e n . c o m ~}$ 